\title{
DEVELOPMENT OF SETS-BASED WITH OUTDOOR LEARNING-METHOD Of STUDENT WORKSHEET TO ADVANCE ENVIRONMENTAL SCIENCE PROCESS SKILL AND ATTITUDE IN A VIIth GRADE HIGH SCHOOL STUDENTS
}

\author{
Claudhia Anandhi Maya, Insih Wilujeng, and Purwanti Widhy Hastuti \\ Science Education, Yogyakarta State University \\ E-mail: claudhiaa89@gmail.com
}

\begin{abstract}
The aims of this research were to (1) produce SETS-based with outdoor learning-method of student worksheet which is valid to advance students 'science process skill and environmental attitude in a VIIth grade high school students based on the validator, (2) know the student respond on SETS-based with outdoor learning-method of student worksheet (3) know the advancement of students 'science process skill after using the color SETS-based with outdoor learning-method of student worksheets and (4) know the advancement of students 'environmental attitude after using the color SETS-based with outdoor learning-method of student worksheets. The sample of this study included 30 students of SMP E class VII 1 Paliyan. Research of the model that is being conducted is $4 \mathrm{~d}$ model comprises define, design, develop, and disseminate. According to results:: (1) The student worksheet developed was valid to advance students 'science process skill and environmental attitude in a VIIth grade high school students according to the validator, with very good category. (2) Student responses on the developed worksheets were very good. (3) Developed the worksheet can advance students science process skill which is shown by a good percentage, medium gains, and suppotted by significant result of paired sample t-test. (3) Developed the worksheet can advance students science process skill which is shown by a good percentage, medium gains, and suppotted by significant result of paired sample t-test.
\end{abstract}

Keywords: environmental attitude, science process skill SETS-based, with outdoor learning-method, student worksheet

\section{INTRODUCTION}

Curriculum in Indonesia currently is the Curricula 2013 who pay attention to the alignment of $\mathrm{KI}, \mathrm{KD}$, materials, activities, indicators, assessment, and learning resources in one integrity learning experience. K-13 also redirect to integrated learning and learning with emphasis three aspects (cognitive, affective, and psychomotor). In addition, the IPA as a way of investigating stressed that learning the IPA is a process to find not only received the results.

The facts on the ground still shows that prioritizes the cognitive aspects of learning, so that aspect of the affective and psychomotor less honed. Based on the results of observation on SMP N 1 Paliyan, the ability of the students in doing process skills SCIENCE (science process skill) still need to be developed. Learners are still hard for observing, measuring, predicting, and communicating. In addition, learners have not yet realized that what human beings certainly have an effect on the environment. This is reflected in the response to the stimulus provided by the teacher. The response of the learners in the form of approval regarding the policy towards learners conservation and environmentally motivated of human satisfaction, well-being and agree that science and technology can resolve all the problems of the environment, not interested in maintaining natural resources through everyday activities, and not be concerned as well as the loss in the event of damage to the environment. The response given by the learners reflect a negative assessment of the environment so that it can be summed up the attitude of the caring environment of the learners is low.

Learning SETS with outdoor learning is the learning method that can sharpen the science process skills and attitudes to care for the environment. This is revealed by the Yager (2012: 3-4) stated that the emphasis on process skills SETS so that the learners are trained in using the skills to solve the permaslahan process and facilitate the identification of the influence of science and technology on society and the environment in the future. Problems presented through exposure to issues and searching the best solutions through exploration can hone the skills of learners 
process along with its relationship to grow the use of science and technology by human effect on the environment as well as the man himself. In addition, Anne (2009: 7) stated that the outdoor learning method SETS with a basis in the development of LKPD facilitates learners to become active learners and provide a real experience to learners in the process applying the skills Science and learning about the influence of science and technology used by humans to the environment as well as the community itself.

Based on problems that have been raised, then the necessary existence of the development of learning materials to cultivate the science process skills and attitudes of concerned lingukungan be LKPD. Therefore, the research carried out under the title "development of LKPD based SETS with Outdoor Learning Methods to foster Science Process Skill and attitude of Caring Environment Learners Class VII junior high school. As for the material used i.e. water pollution, air pollution, and pollution of soil with the theme of "Still bersihkah natural resource?".

\section{RESEARCH METHODS}

This research is a research and development by implementing $4 \mathrm{~d}$ models in accordance with Thiagarajan, Semmel, \& Semmel (1974:6-9).

\section{Time and place of Research}

This research was carried out in April 2017 years lessons 2016/2017 precisely on the even semester in SMP N 1 Paliyan.

\section{Subject}

The subject in this study are students of class VIII E SMP N 1 Paliyan totalling 30 learners.

\section{Object of Research}

The object in this research is LKPD based SETS with outdoor learning methods to foster science process skill and attitude of caring environment learners Class VII junior high school.

\section{Procedure}

This research consists of four stages, namely the stage define, design, develop, and disseminate. Stage define consists of the initial analysis, analysis of the learners, analysis tasks, an analysis of the concept, and the formulation of the purpose of learning. Stage design consists of a drafting instrument, selection of media or materials, choice of format, and the initial draft (draft 1). Develop phase consists of validation by expert lecturers and teachers of the IPA, and then conducted trials of development. Disseminate stage done in limited spread to the teacher at the JUNIOR HIGH SCHOOL N 1 IPA Paliyan, teacher IPA SMP N 1 Wonosari, and learners Class VII E SMP N 1 Paliyan.

\section{Data, Instruments, and Data collection Techniques}

The instruments used in this research in the form of sheets validation LKPD based SETS with method of outdoor learning, learner response against the now LKPD observation sheet, keterlaksanaan learning, pretest-posttest problem and the observation sheet Science process skill, as well as the now the attitude of care for the environment.

Data Analysis Techniques

Technique of data analysis used in this study are as follows.

1. Analysis Of The Results Of The Validation LKPD

Data obtained from the results of the validation are analyzed to find out the feasibility of LKPD IPA with based on table 1.

Table 1. The actual Score Conversion became a value Scale of four (Mardapi, 2008: 123)

\begin{tabular}{llcl}
\hline No. & Score range & Value & Category \\
\hline 1. & $\mathrm{X}>\mathrm{Xi}+1 \mathrm{SBx}$ & A & Very good \\
\hline 2. & $\mathrm{I}+1 . \mathrm{SBx}<\mathrm{Xi}></ \mathrm{Xi}>$ & $\mathrm{B}$ & Good \\
\hline 3. & $\mathrm{Yi} \mathrm{Xi}>\mathrm{SBX}-1$. & $\mathrm{C}$ & Enough \\
\hline 4. & $\mathrm{X}>\mathrm{Yi}-1 . \mathrm{SBx}$ & $\mathrm{D}$ & Less \\
\hline
\end{tabular}

Source: Mardapi (2008: 123)

Then reliability and validation expert lecturers and teachers IPA can be set with the formula Borich (1994: 385). The results of the validation LKPD IPA reliability if it has reliability $>75 \%$. 
2. Analysis of Learner Response against LKPD

Data obtained from the results of the validation are analyzed to find out the feasibility of LKPD IPA with based on table 1.

3. Analysis of The Science Process Skill

a. Pretest-Posttest Data Analysis

Pretest and posttest scores from each learner is analyzed using normalized gain score as follows:

$$
<g>=\frac{T 2-T 1}{100-T 1} \times 100 \%
$$

Source: Hake (1999: 1)

The significance of the growth of the science process skill is analyzed using paired samples ttest in SPSS applications.

b. Analysis Of The Observation Sheet

The percentage of data ketercapaian science process skill learners gained from observation sheet observations observer.

$(\mathrm{P})=\mathrm{x} 100 \%$

The $\mathrm{P}$ value obtained in the form of a percentage of the data in the form of quantitative data which will then be converted to qualitative data by using table 2 .

Table 2. The Percentage Of Mastery Of The Science Process Skill

\begin{tabular}{ccc}
\hline $\begin{array}{c}\text { Level of } \\
\text { mastery }\end{array}$ & Value & Category \\
\hline $86-100 \%$ & $\mathrm{~A}$ & Very Good \\
\hline $76-85 \%$ & $\mathrm{~B}$ & Good \\
\hline $60-75 \%$ & $\mathrm{C}$ & Enough \\
\hline $55-59 \%$ & $\mathrm{D}$ & Less Good \\
\hline$\leq 54 \%$ & $\mathrm{E}$ & Very Unfavourable \\
\hline
\end{tabular}

(Purwanto, 2009: 103)

4. Analysis Of Attitude Care For The Environment

Now the attitude data were analyzed using a normalized environment care gains score. The significance of the growth of the attitude of care for the environment are analyzed using paired samples t-test in SPSS applications.
1. LKPD validation Based SETS with Outdoor Learning Method

LKPD based SETS with outdoor learning method developed validated by two professors and two expert teachers IPA. Aspects appraised include the appropriateness of content, presentation, linguistic, and kegrafisan. Based on the assessment of expert lecturers and teachers of SCIENCE, overall LKPD developed stated worth with excellent category (A).

The consistency of the judgments of the validator, determined by performing reliability analysis by using the Percentage of Agreement. Reliability analysis based on the results obtained the percentage above $75 \%$ i.e. of $97.01 \%$ so that assessment revealed reliability.

2. Learner Response

Dididk participant response against LKPD based SETS with outdoor learning aspects of the feasibility of the method is the content, the presentation, linguistic, and kegrafikan. Based on the assessment by the students shows the response with excellent category (A).

3. The Growth of The Science Process Skill Learners

a. Analysis of Pretest-Posttest

The result of the growth of the science process skill learners in mind based on pretest and posttest results shown in table 3 below.

Table 3. Pretest and Posttest Results data

\begin{tabular}{lll}
\hline \multicolumn{2}{l}{ Percentage $(\%)$} & Gain Score \\
\cline { 1 - 2 } Pretest & Pretest & \\
\hline 62.17 & 82.22 & 0.53
\end{tabular}

Category Enhancement Is being

Paired sample t-test showed that science process skill learners experiencing significant growth after using the significance value LKPD (Sig) of 0.000 .

b. Data Analysis The Results Of The Observation

The results of the observations of science process skill served table 4 . 
Table 4. Data Ketercapaian Science Process Skill through the Observation Sheet

\begin{tabular}{|l|l|l|l|l|}
\hline \multirow{2}{*}{ Aspects } & \multicolumn{3}{|c|}{ Percentage (\%) } & \multirow{2}{*}{$\begin{array}{c}\text { Average } \\
\end{array}$} \\
\cline { 2 - 4 } & Act. 1 & Act. 2 & Act. 3 & \multicolumn{1}{|c|}{} \\
\hline Observing & 73.33 & 90.00 & 99.17 & 87.50 \\
\hline Predicting & 44.17 & 83.33 & 91.11 & 71.39 \\
\hline Measuring & 73.67 & 76.30 & 86.97 & 78.98 \\
\hline $\begin{array}{l}\text { Communic } \\
\text { ating }\end{array}$ & 61.85 & 69.11 & 87.33 & 72.77 \\
\hline Average & & & 78.65 \\
\hline Category & Good \\
\hline
\end{tabular}

Based on the results of a pretest-posttest and observations can be known that LKPD based SETS with outdoor learning method can foster science process skill. SETS can facilitate science process skill in accordance with Yager (2012: 3-4) that SETS an emphasis on skills in the process so that the learners are trained in the use of process skills to solve problems. In addition, Anne (2009: 7) stated that the outdoor learning methods can support SETS in facilitating learners into active learners and provide a real experience to learners to apply the science process skill. So, LKPD based SETS with outdoor learning method capable of fostering science process skills learners.

4. The Growth Of Environmental Caring Attitude Of Learners

The result is nothing attitude of caring environment learners based on question form is presented in table 5 .

Table 5. Recap of Attitude care for the environment through the now

\begin{tabular}{lllll}
\hline $\begin{array}{l}\text { Avera } \\
\text { ge } \\
\text { before }\end{array}$ & $\begin{array}{l}\text { Before } \\
\text { Percent } \\
\text { age (\%) }\end{array}$ & $\begin{array}{l}\text { Caring } \\
\text { attitude } \\
\text { domain } \\
\text { environme } \\
\text { nt }\end{array}$ & $\begin{array}{l}\text { Avera } \\
\text { ge } \\
\text { After }\end{array}$ & $\begin{array}{l}\text { After } \\
\text { The } \\
\text { Percent } \\
\text { age (\%) }\end{array}$ \\
\hline 12.30 & 61.50 & $\begin{array}{l}\text { Motivated by } \\
\text { Anthropocent } \\
\text { ric } \\
\text { Conservation } \\
\text { Concern }\end{array}$ & \\
& & & \\
\hline at 11 & 55.67 & $\begin{array}{l}\text { Confidence in } \\
\text { Science and } \\
\text { Technology }\end{array}$ & $15: 43$ & 77.17 \\
\hline 14.57 & 72.83 & Personal & at 17 & 87.83 \\
\hline
\end{tabular}

\begin{tabular}{lllll}
\hline \multicolumn{6}{c}{$\begin{array}{l}\text { Conservation } \\
\text { Behaviour }\end{array}$} \\
\hline 15.30 & 76.50 & $\begin{array}{l}\text { Ecocentric } \\
\text { Concern }\end{array}$ & $18: 57$ & 92.83 \\
\hline at 13 66.63 & $\begin{array}{l}\text { The average } \\
\text { attitude of } \\
\text { care for the } \\
\text { environment }\end{array}$ & & \\
& & & \\
\hline
\end{tabular}

Based on these results it can be noted that the percentage of product environmental care attitude of learners after using LKPD based SETS with outdoor learning methods i.e. $84.29 \%$ with categories either. This is in line with the statement Yager (2012: 3-4) that SETS to facilitate identification of the influence of science and technology on society and the environment. In addition, Anne (2009: 7) stated that the outdoor learning methods can support SETS in facilitating learners learn directly about the relationship in environmental science, technology, society, and environment. So, LKPD based SETS with outdoor learning method capable of fostering an attitude of caring environment of the learners.

\section{SUMMARY AND ADVICE}

\section{Summary}

1. Been generated LKPD based SETS with outdoor learning method that deserves to be used as well as feasible to develop science process skill and attitude of caring environment learners Class VII junior high school. LKPD developed feasibility in terms of valuation experts (the expert appraisal) and test development (developmental testing). The assessment of the suitability of the content of the component include LKPD, linguistic component, component rendering, and kegrafikan components. The results of the assessment of expert lecturers and teachers each IPA component obtains the value of A with the category very well.

2. The response of the students against the conformity of the components reviewed LKPD content, linguistic component, component 
rendering, and worth A kegrafikan component with category very well.

3. Based on the trial results-based LKPD SETS with outdoor learning method in the field can grow the science process skill learners JUNIOR Class VII with normalized earnings gains score based on pretest-posttest of 0.53 by category being. Average mastery of science process skill overall from the first meeting until the third meeting through the observation sheet is of $78.65 \%$ with categories either. Conclusion based on the paired t-test is that mastery of the science process skill after using LKPD based SETS with outdoor learning method is greater than the science process skill before using LKPD based SETS with outdoor methods learning.

4. Based on the trial results-based LKPD SETS with outdoor learning method in the field can cultivate an attitude of caring environment learners JUNIOR Class VII with normalized earnings gains score based on the analysis of the question form of 0.53 by category being. Conclusion based on the paired t-test is that mastery of attitude care for the environment after using LKPD based SETS with outdoor learning method is larger than the attitude of care for the environment before using LKPD based SETS with method outdoor learning.

\section{Advice}

1. Students are directed to save time in doing the observing or measuring so that learners do not run out of time in conducting the activity of predicting.

2. The domain of attitude care for the environment in the form of confidence in science and technology which are grown on the research further to be more emphasized so that students no longer rests on specific science and technology in the settlement of problems the environment.
Anne, P. (2009). Foundation Phase Outdoor Learning Handbook (electronic version). Downloaded from www. learning. gov. whales on November 30, 2016.

Borich, G.D. (1994). Observation Skills for Effective Teaching. New York: Mc Graw-Hill Companies.

Hake, R.R. (1998). Interactive-Engagement Versus Traditional Methods: With Sixthousand Students Survey of Mechanics Test Data for Introductory Physics Course. American Journal of Physics, 66 (1), 64-74.

Mardapi, D. (2008). Engineering Drafting Instrument tests and Nontes. Yogyakarta: Publisher Partners Scholar.

Purwanto, N. (2002). Principles and techniques of evaluation of teaching. Bandung: PT. Teen Rosdakarya Yager, S.O. (2012). The Role of Student and Teacher Creativity in Aiding Current Reform Efforts in Science and Technology Education. National Forum Of Applied Educational Research Journal Volume 25, Number 3. 1-2.

Thiagarajan, S., Semmel, D.S., \& Semmel, Myocardial Infarction And (1974). Instructional Development for Training Teachers of Exceptional Children. Bloomington, Indiana: Indiana University. 